\title{
Echinoid associations with coral habitats differ with taxon in the deep sea and the influence of other echinoids, depth, and fishing history on their distribution
}

\author{
Stevenson Angela ${ }^{1,{ }^{*}}$, Davies Jaime S. ${ }^{2}$, Williams Alan ${ }^{3}$, Althaus Franziska ${ }^{3}$, Rowden Ashley A. ${ }^{4}$, \\ Bowden David A. ${ }^{4}$, Clark Malcolm R. ${ }^{4}$, Mitchell Fraser J. G. ${ }^{1}$
}

${ }^{1}$ Trinity Coll Dublin, Sch Nat Sci, Dublin 2, Ireland.

2 IFREMER, Dept LEP, Ctr Brest, Plouzane, France.

${ }^{3}$ CSIRO Oceans \& Atmosphere, Marine Labs, Hobart, Tas, Australia.

${ }^{4}$ Natl Inst Water \& Atmospher Res NIWA, Wellington, New Zealand.

* Corresponding author : Angela Stevenson, email address : stevenan@tcd.ie

\begin{abstract}
:
Patterns of habitat use by animals and knowledge of the environmental factors affecting these spatial patterns are important for understanding the structure and dynamics of ecological communities. Both aspects are poorly known for deep-sea habitats. The present study investigates echinoid distributions within cold water coral (CWC) habitats on continental margins off France, Australia, and New Zealand. It further examines the influence of habitat-related variables that might help explain the observed distribution of echinoid taxa.
\end{abstract}

Six echinoid taxa were examined from video and photographic transects to reveal taxon-specific distribution patterns and habitat-related influences. The Echinoidea were found in all habitats studied, but tended to aggregate in architecturally complex habitats associated with living cold-water corals. However, a taxon-specific investigation found that such associations were largely an artefact of the dominant taxa observed in a specific region. Despite the food and shelter resources offered to echinoids by matrix-forming coral habitats, not all taxa were associated with these habitats, and some had a random association with the habitats examined, while others displayed non-random associations.

Echinoid distribution was correlated with several variables; the presence of other echinoids, depth, and fishing history were the most influential factors.

This study indicates that image data can be a useful tool to detect trends in echinoid habitat associations. It also suggests that refinement of the methods, in particular with studies conducted at a more precise taxon and habitat scale, would facilitate better quantitative analyses of habitat associations and paint a more realistic picture of a population's ecology. Most deep-sea ecological studies to date have been conducted at a relatively coarse taxonomic and habitat resolution, and lack 
sufficient resolution to provide useful information for the conservation of vulnerable deep-sea habitats.

\section{Highlights}

- Group Echinoidea and taxon-specific habitat associations in a region differ. Not all taxa associate with matrix-forming coral habitats, some are random and not. Distribution correlated with presence of other echinoids, depth, and fishing history. Image data can be a useful tool to detect trends in echinoid habitat associations. Precise taxon and habitat scale paint a more realistic picture of a pop. ecology.

Keywords : Cidaroidea, Echinothuriidae, Fishing intensity, Habitat characteristics, Predator activity, Sea urchin 


\section{Introduction}

Understanding patterns of habitat use is an important aspect of animal ecology as it is the necessary first step towards understanding the ecological interactions between species and their predators, prey, competitors, and environment that shape these distributions (Heithaus et al., 2006). Understanding habitat use is particularly important for ecologically important taxa like echinoids, which play a pivotal role in nutrient recycling and system engineering of shallow-water habitats (e.g. Bromley, 1978; Glynn et al., 1979; Sammarco, 1980; Koike et al., 1987; Jumars et al., 1990; Scheibling \& Hamm, 1991; Bak, 1994; Glynn, 1997; Sauchyn and Scheibling, 2009). In tropical shallow-water coral reef habitats, echinoid species (although not facultative inhabitants of reefs) have a range of effects on the distribution of coral, as well as the abundance, species composition, and the diversity of associated species (Sammarco, 1982). Echinometra viridis A. Agassiz, 1863, for example, grazes locally and creates small algae-free patches on reefs, while Diadema spp. are more efficient grazers and clear algae from larger areas of the reef, even at low population densities $\left(<16\right.$ inds $\left.\mathrm{m}^{-2}\right)$ (Sammarco, 1982). Diadema antillarum Philippi, 1845 appears to affect coral settlement, while E. viridis does not. Echinothrix diadema and E. calamaris consume coral among their diet of sponges and algae (Schultz 2005, Miskelly 2002). In these shallow coral habitats, species-specific impacts are dependent on habitat preferences whereby species have evolved and adapted ways of exploiting different parts of the reef to allow for coexistence with competitors (Coppard and Campbell, 2005). For example, Echinometra mathaei (Blainville, 1825), Diadema setosum (Leske, 1778), Diadema savignyi (Audouin, 1809), Echinothrix diadema (Linnaeus, 1758) and Echinothrix calamaris (Pallas, 1774), each associate with different parts of the reef (Coppard and Campbell, 2005). While important speciesspecific reef interactions and habitat associations have been described for shallow-water systems, relatively few studies have examined interactions and associations in cold water coral (CWC) habitats.

Coral habitats in the deep sea are often observed in the form of dense matrixforming corals and their broken skeletal remains. These habitats provide structure for various organisms, increasing local benthic diversity (Henry and Roberts, 2007). The coral infrastructure may offer refuge from predators where complex habitats provide 
more shelter from predators than those habitats that are less complex (Etnoyer and Morgan, 2005). In this respect, deep-sea echinoids have been found to primarily seek refuge from predators in the coral infrastructure rather than arrange themselves in defensive aggregates (Stevenson et al., 2014). CWCs typically form architecturally complex habitats that are thought to intercept organic matter in the water column that would otherwise not settle on the sea floor (Gage and Tyler, 1992; Freiwald et al., 2004; van Oevelen et al., 2009). This accumulation of detrital material and associated organisms on the dead coral infrastructure, as well as the protein rich mucus layer on living coral, may all serve as a food source for deep-sea echinoids (Stevenson and Rocha, 2013; Stevenson and Mitchell, 2016). Thus, in the deep sea, echinoid selection for complex habitats may be linked to predator avoidance tactics and availability of food.

Understanding the environmental features driving species-specific distributions is important for the proper development of wildlife management and conservation plans (Calenge, 2007; Dumas et al., 2007). The distribution and abundance of echinoids in shallow-water coral reefs have been attributed to a combination of biotic and abiotic factors, such as predation, behavioural processes, wave activity, water depth, substratum composition, and food availability (Lawrence, 1975; McClanahan, 1988; Dotan, 1990; Coppard and Campbell, 2005; Dumas et al., 2007). Very little is known about the environmental factors that influence echinoid distribution in CWC habitats.

In addition to the physical habitat properties of the coral itself, at least six habitatrelated predictor variables have been identified that might play a role in shaping echinoid distributions: (1) competition: the presence of other echinoids leading to a speciesspecific hierarchy on nutritiously valuable substrates in the deep sea (Stevenson and Mitchell, 2016); (2) predation: predator presence influencing habitat choice (Stevenson et al., 2014); (3) water depth: bathymetric stratification is commonly observed in deep-sea communities often linked to factors correlated with depth such as temperature, oxygen concentration, food availability and pressure (Clark et al., 2010a); (4) geomorphology (e.g. slope vs. seamounts): features possess a different mosaic of habitats which may lead to differences in species associations and distributions (Cartes et al., 2009; Bo et al., 2011); (5) proximity of features (e.g. seamounts): proximity may lead to connectivity for species colonisation between nearby features (Miller et al., 2010); and (6) fishing history: 
removal of substrate and/or habitat forming organisms by fishing activities may alter the community composition, certain taxa might be more resistant to fishing impacts or are early colonisers (see Althaus et al., 2009, Clark and Rowden 2009).

The aims of this study were to:

(i) Document the distribution of echinoids in CWC habitats;

(ii) Determine whether echinoids are associated with specific CWC habitats;

(iii) Explore relationships between echinoid distribution and six habitat-related predictor variables;

(iv) Determine if the patterns of distribution differ with taxonomic resolution.

\section{Materials and methods}

\subsection{Study areas}

Patterns of habitat associations by deep-water echinoids were investigated in three geographic regions: waters off France in the NE Atlantic, and waters off Australia and New Zealand in the SW Pacific. These study areas were chosen on the basis of high quality video and still image data taken at deep-sea habitats, including coral habitat, which were readily available from surveys conducted by L'Institut Française de Recherche pour l'Exploration de la Mer (Ifremer,) the National Institute of Water and Atmospheric Research (NIWA), and the Commonwealth Scientific and Industrial Research Organisation (CSIRO). Analyses of data from these study areas facilitated the comparison of patterns across a broad geographic range. The data for the Australian and New Zealand study areas permitted comparisons of patterns of habitat association in nearby regions with similar habitat type. The French study area had fewer available habitat typologies than Australia and New Zealand, so comparison of distribution patterns in the French study area to those of the SW Pacific allowed for an additional investigation of shifts in distribution in the presence of a smaller range of habitat types.

In the French study area, data were collected from continuous video transects in five neighbouring canyons (Croisic, Guilvinec, Petite Sole, Crozon, and MorgatDouarnenez canyons) in the Bay of Biscay, NE Atlantic (Fig. 1A). The Bay of Biscay lies 
on the western coast of France and extends from the coast of Brest south to the Spanish border and west to Cape Ortegal. Canyons sampled in this study ranged in depth between 524 to $1324 \mathrm{~m}$. A total area of 7.03 ha was sampled in this study area. Fishing data were unavailable.

In the Australian study area, data were compiled from photographic surveys south of Tasmania, SW Pacific (Fig. 1B). A total area of 1.63 hectares (ha) was surveyed across 17 seamounts and 3 slope areas on the continental margin, south of Tasmania. Two areas were studied: the 'Tasman Fracture' and the 'Huon' areas, both of which are composed of a steep continental slope and two fields of adjacent seamounts. The seamounts are coneshaped mounds with summit depth of 700-1400 m, and elevation from the surrounding seafloor of 200-300 m (Dunstan et al., 2012). Deep-sea fisheries in the area started in the early 1990s, certain seamounts were subsequently closed to fishing in 2001 while others still remain fished (Williams et al., 2010). Further details about site fishing histories are outlined in Table 1.

In the New Zealand study area, data were obtained from the 'Graveyard seamount complex' which is located on the northern flank of the Chatham Rise, SW Pacific (Fig. 1C). This complex consists of 20 seamounts spanning summit height depths of 750 to $1250 \mathrm{~m}$ (Mackay et al., 2005) and elevations of 100 to $300 \mathrm{~m}$ (Clark et al., 2010b). A total area of 2.84 ha was surveyed in this study area. The study focused on six of these seamounts, four trawled (Diabolical, Morgue, Zombie, Graveyard) and two unfished (Ghoul, Gothic). The region has been heavily trawled since the 1990s, but three seamounts were closed to trawling in 2001 (Clark and Rowden, 2009). Note that Morgue's SW ridge has never been trawled due to its steep walls. Further site details can be found in Clark et al. (2010b). 

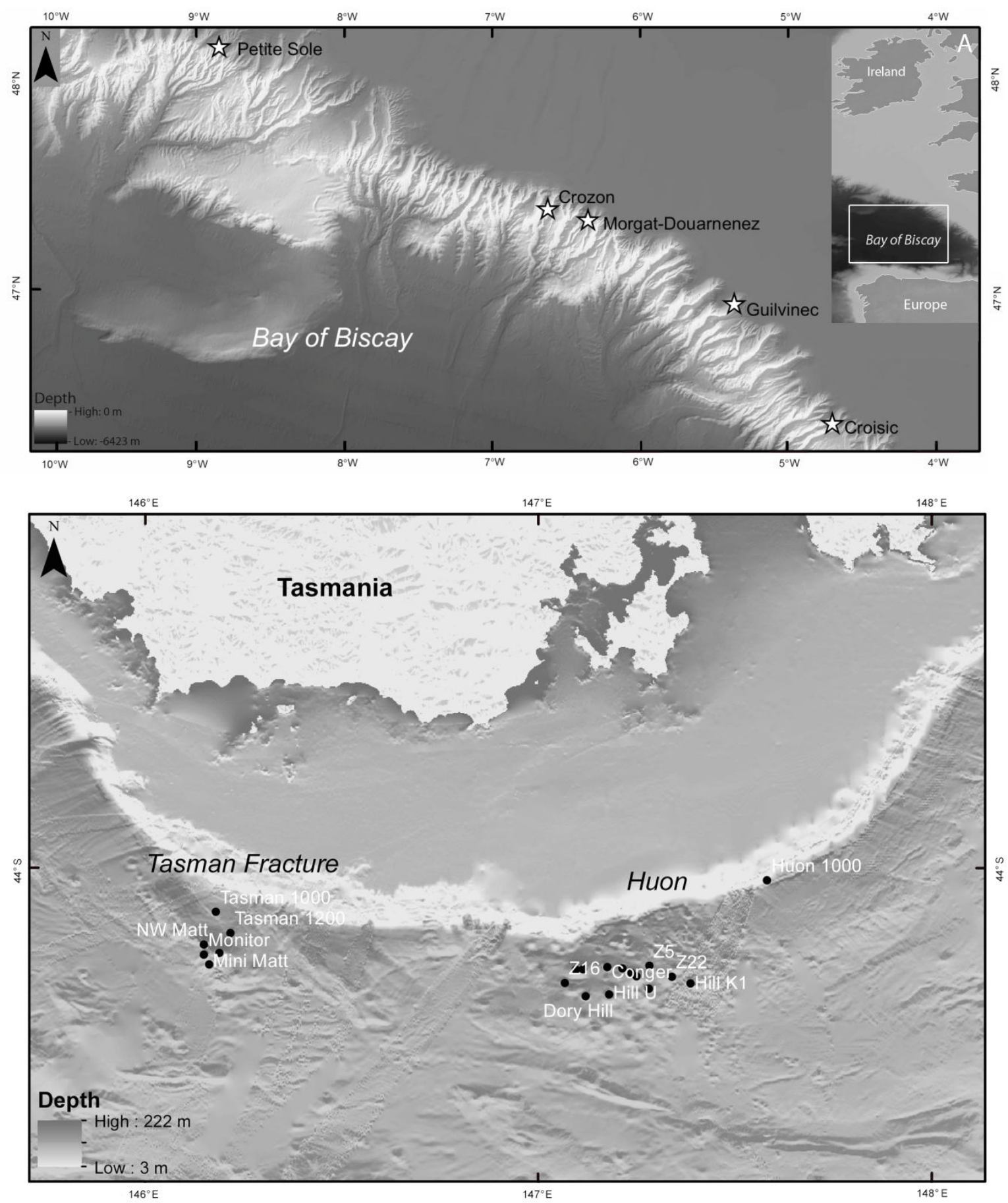


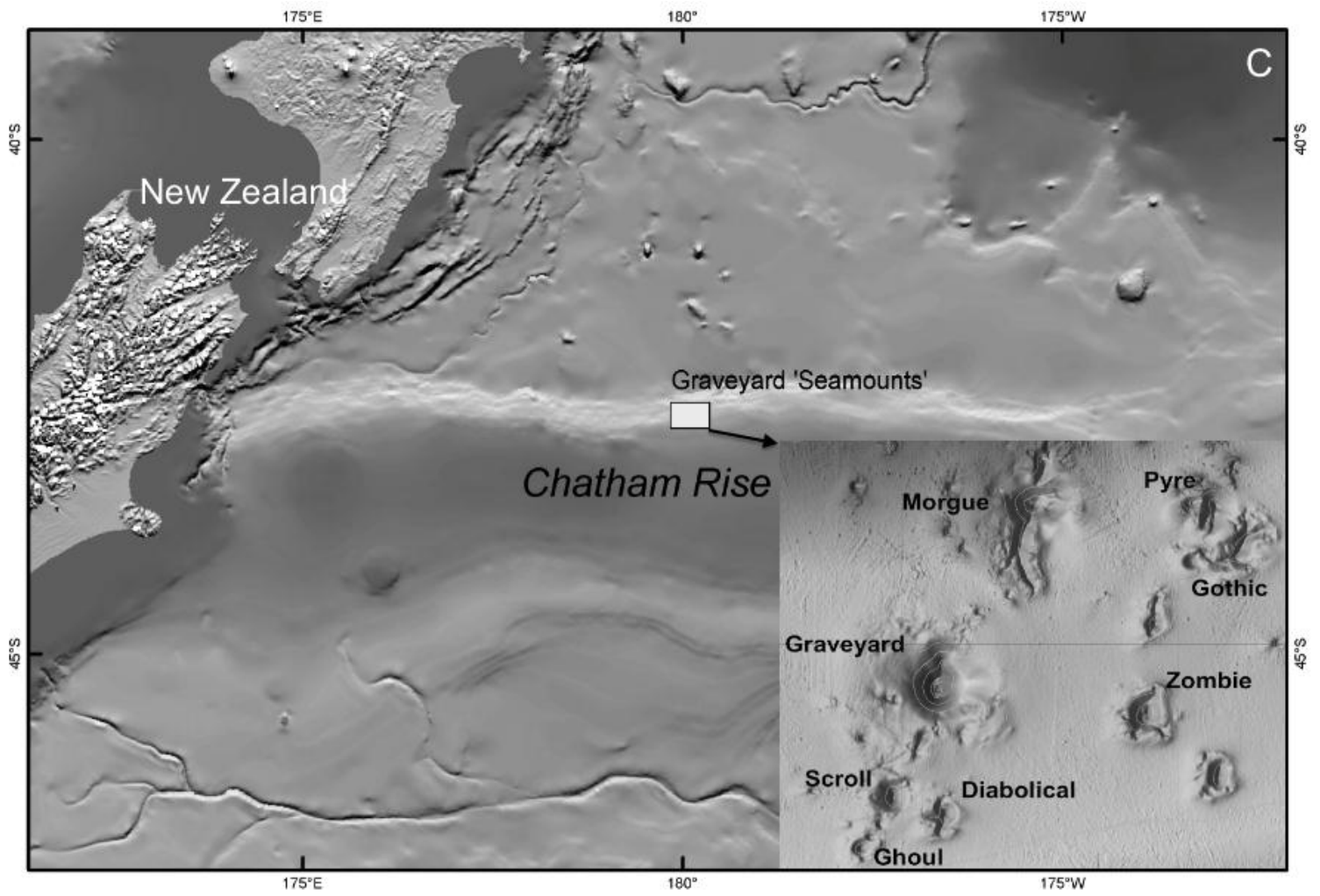

Fig. 1. Location of the study areas and sampling sites in the NE Atlantic and SW Pacific. (A) Five canyons in the Bay of Biscay, NE Atlantic; (B) 21 seamounts and three slope sites of the 'Tasman Fracture' and 'Huon' areas, south of Tasmania, SW Pacific; and (C) eight seamounts on the Chatham Rise, east of New Zealand, SW Pacific.

Table 1. Details for French, Australian, and New Zealand sites. For Australian and New Zealand sites, trawling has ceased in the area unless otherwise indicated. TF - Tasman Fracture.

\begin{tabular}{|c|c|c|c|c|c|c|c|}
\hline $\begin{array}{l}\text { Geographic } \\
\text { region }\end{array}$ & Area & Site & $\begin{array}{c}\text { No. } \\
\text { transects }\end{array}$ & $\begin{array}{c}\text { Seabed } \\
\text { area } \\
\text { analyzed } \\
\text { (ha) }\end{array}$ & $\begin{array}{l}\text { Depth } \\
\text { range }(\mathbf{m})\end{array}$ & $\begin{array}{c}\text { Distance to } \\
\text { nearest } \\
\text { seamount } \\
(\mathbf{k m})\end{array}$ & Fishing history \\
\hline \multirow[t]{5}{*}{ France } & $\begin{array}{l}\text { Bay of } \\
\text { Biscay }\end{array}$ & Croisic canyon & 3 & 0.888 & $694-1048$ & - & - \\
\hline & & Guilvinec canyon & 5 & 1.032 & $778-941$ & - & - \\
\hline & & Petite Sole canyon & 3 & 1.715 & $524-981$ & - & - \\
\hline & & Crozon canyon & 2 & 1.028 & $108-1394$ & - & - \\
\hline & & $\begin{array}{l}\text { Douarnenez-Morgat } \\
\text { canyon }\end{array}$ & 2 & 2.146 & $697-1195$ & - & - \\
\hline \multirow[t]{6}{*}{ Australia } & Huon & Huon 1000 slope & 3 & 0.1189 & $618-1116$ & 19.07 & Never trawled \\
\hline & & Hill U seamount & 3 & 0.1245 & 1099-1314 & 2.64 & Never trawled \\
\hline & & Dory Hill seamount & 1 & 0.0661 & 1091-1469 & 3.63 & Never trawled \\
\hline & & $\begin{array}{l}\text { Sister } 2 \text { (north) } \\
\text { seamount }\end{array}$ & 2 & 0.0924 & $902-1350$ & 1.46 & Trawled \\
\hline & & Hill K1 seamount & 3 & 0.0506 & $1248-1817$ & 4.23 & Never trawled \\
\hline & & Z22 seamount & 1 & 0.0475 & $1236-1490$ & 4.23 & Never trawled \\
\hline
\end{tabular}




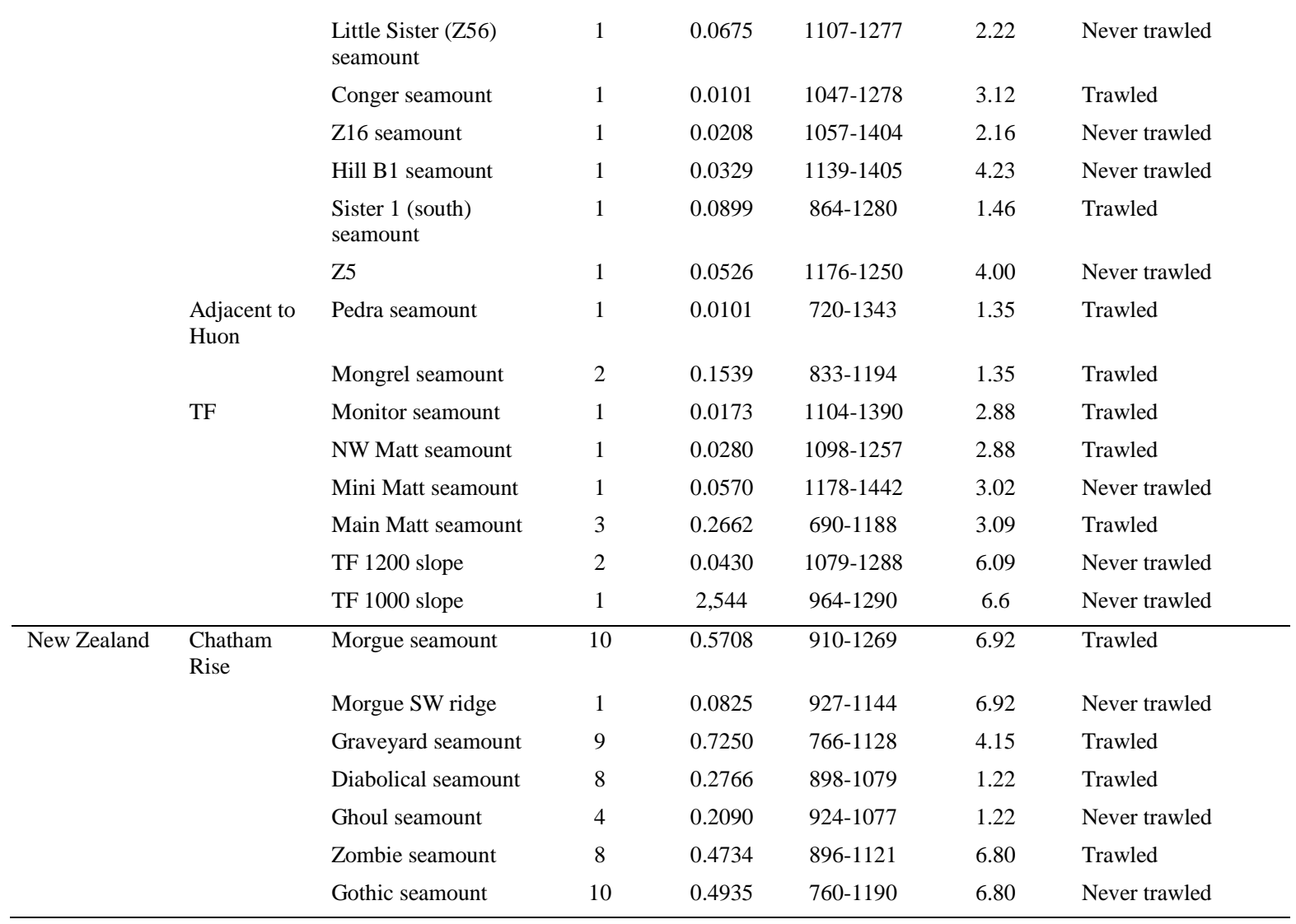

2.2 Extracting data from photographic transects; continuous video and photographic surveys

In the French study area, 15 continuous video transects (consisting of a total of $25 \mathrm{hrs}$ of video recording) were captured with the vertically facing high definition camera of a remotely operated vehicle (ROV) (Ifremer, survey BOBECO, 'NO Pourquoi Pas?'). Transects were close to one another but never overlapping, and conducted by the ROV at a height of 2-5 $\mathrm{m}$ above the seafloor. Transect width (determined by the width of the field of view) varied with camera altitude (between $2 \mathrm{~m}$ and $12 \mathrm{~m}$ ). Further details can be found in Khripounoff et al. (2014).

In the Australian study area, a total of 30 photographic transects were conducted using a towed camera system (Shortis et al. 2008) with stereo cameras mounted at an oblique angle $\left(50^{\circ}\right)(\mathrm{CSIRO}$, survey SS200611, RV Southern Surveyor). Photographic transects were run from summit to base of the seamount, maintaining the camera system at a target altitude of 2-4 m above the seabed. Images were taken at $10 \mathrm{~s}$ intervals, a total 
of 3,640 images were analysed. Images were individually geo-referenced which allowed for the determination of depth estimates and the calculation of distance to the nearest seamount feature (Table 1). Further details can be found in Williams et al. (2010).

In the New Zealand study area, a total of 50 photographic transects were conducted using a towed camera system with a vertically mounted still camera (NIWA, survey TAN0905, ' $R V$ Tangaroa'). The camera system is described by Hill (2009). Photographic transects were, as in the Australian study area, run from summit to base of the seamount, maintaining the camera frame at a target altitude of 2-4 $\mathrm{m}$ above the seabed. Images were captured every $15 \mathrm{~s}$, a total of 6,620 images were analysed. Depth and position of sites were obtained from towed camera navigation files which allowed for the determination of depth estimates and the calculation of distance to the nearest seamount feature (Table 1). Further site details can be found in Clark et al. (2010b).

\subsection{Image analyses}

\subsubsection{Habitat type}

Frame grab images were captured at $1 \mathrm{~min}$ intervals for the entire length of each video transect from the French study area. Full image annotation was conducted on these subsamples of the transect (i.e. the frame grab images) such that the whole content of the image was classified to one category, which was determined by the dominant coral or other substrate in the image. The proportion of each habitat within that particular transect was then calculated from this score. The proportion of each habitat type represented in the transect $(\mathrm{PH})$ was then estimated from these data. For the two SW Pacific study areas, the amount of habitat encountered was determined by scoring the habitat type in all images analyzed and calculating its total area.

Habitat types (the dominant biotic or abiotic substrate characterizing an area of the site under observation) were determined for each image. There were 17 habitat types in three higher level groups: five categories of non-living habitats (rocky or sediment substrates), three categories based on dead coral frameworks and eight categories based on living coral frameworks (Table 2). These categories were formulated from the CoralFISH Northeast Atlantic and Mediterranean Cold-Water Coral Habitats Catalogue 
(Guillaumont et al., 2016). The living coral framework categories include three categories of CWC habitats; the distinction between these is noteworthy. 'Living CWC reefs' primarily possess reef-building stony coral, such as Lophelia pertusa (Linnaeus, 1758) and Madrepora oculata Linnaeus, 1758 (in French study area) and M. oculata, Solenosmilia variabilis Duncan, 1873 and Enallopsammia rostrata (Pourtalès, 1878) (in Australian and New Zealand study areas) while 'mixed CWCs' include gorgonians and stylasterids, and are not dominated by reef-building stony coral. A 'colonized CWC reef' primarily consists of reef-building stony coral colonized by corals such as gorgonians and antipatharians that are growing on the dead/live stony coral reef.

Table 2. Habitat types, categorized by high level groups that were used in the study. CWC - Cold-water coral.

\begin{tabular}{|ll|}
\hline High level groups & Specific categories \\
\hline Non-living habitats: & Bedrock \\
Boulders & Gravel \\
& Sediment \\
& Sand overlay \\
\hline Dead coral framework: & Dead CWC reef framework \\
& CWC rubble \\
& CWC remains \\
\hline Living coral framework: & Living CWC reef \\
Mixed CWCs \\
Colonised CWC reef \\
Loosely-packed framework \\
Isolated colonies of Scleractinia on hard substrate \\
Isolated colonies of Scleractinia on soft substrate \\
Stylasterids (on hard substrate) \\
Gorgonians on hard substrate \\
Gorgonians on soft substrate \\
\end{tabular}

\subsubsection{Echinoid taxonomic resolution}

Analyses were undertaken at two taxonomic resolutions; first as class Echinoidea and second at a lower taxonomic level. For the latter, species level identification was attempted for all observations, however some were grouped into the higher level taxa, where they could not be resolved to species level from image data: family 
Echinothuriidae in all study areas and subclass Cidaroidea in the New Zealand study area. Cidaris cidaris (Linnaeus, 1758) and Echinothuriidae were observed in the French study area. Dermechinus horridus (A. Agassiz, 1879), Caenopedina otagoensis McKnight, 1968, C. porphyrogigas Anderson, 2009, Echinus multidentatus (H.L. Clark, 1925), Histocidaris purpurata (Thomson, 1872) and Echinothuriidae were observed in the Australian region. C. porphyrogigas, Echinothuriidae and Cidaroidea in the New Zealand study area.

\subsubsection{Calculation of echinoid abundance and distribution}

Whole image screening was used to estimate the abundance of echinoids in video (in French study area) and photographic (in Australian and New Zealand study areas) transects. For the French study area, a frame grab image was taken for every echinoid encountered along the video transect. The density of echinoid species X (ED) in each habitat type (ES) was calculated using equation (1), where the total area of each transect (ha; TA) was calculated from ArcGIS area matrices generated by Adelie software (http://flotte.ifremer.fr/fleet/Presentation-of-the-fleet/Underwater-systems/ADELIE), and $\mathrm{PH}$ represents the proportion of that habitat type found in the transect. The total area observed at each site is provided in Table 1.

$$
\mathrm{ED}=\mathrm{ES} /(\mathrm{PH} \cdot \mathrm{TA})
$$

For the Australian and New Zealand study areas, echinoid species were identified and counted in each image and densities in photographic transects were calculated as follows. Image area and habitat type were assigned to both the echinoid occupied and unoccupied images. From this, echinoid counts were divided by the total seabed area observed for each transect (consisting of both occupied and unoccupied images). For the Australian images, seabed of a defined area within the oblique field of view was calculated using stereo photogrammetric methods (Althaus et al., 2009). The seabed area for the images taken in the New Zealand study area were calculated using parallel laser pointers (20 cm apart) and measured with ImageJ. Where the laser dots were absent or obscured in the image, area was estimated based on the size of the organisms in the 
image. The total areas surveyed for the sites in both study areas in the SW Pacific are provided in Table 1.

\subsubsection{Predators}

The presence of predators encountered in each image was noted. Predators of deep-sea echinoids are not well documented, but fishes such as Chimaera fulva Didier, Last \& White, 2008 and Chimaera lignaria Didier, 2002 are known to feed on deep-sea echinoids (Walker et al., 2008); Molva molva (Linnaeus, 1758), Alepocephalus bairdii Goode \& Bean, 1879, Epigonus telescopus (Risso, 1810), Helicolenus dactylopterus (Delaroche, 1809), and some members of the Notacanthidae are known to include echinoderms in their diet (Howell et al., 2009). Rays and other sharks may also supplement their diet with echinoids (Walker et al., 2008; Howell et al., 2009). Decapods and octopi have been observed predating on deep-sea cidaroids (Stevenson personal observations). In this study, the presence of Chimaera spp., Molva molva, Mora moro (Risso, 1810), Lepidion spp., Trachyscorpia spp., sharks, rays, and octopi, as well as decapods Bathynectes spp., Chaceon affinis (A. Milne-Edwards \& Bouvier, 1894), and other unidentified crabs were noted as potential predators along each transect.

\subsection{Statistical analyses}

All statistical analyses were performed in R version 3.0.0 (R Core Team, 2013). For all tests, significance was determined at $\mathrm{P}<0.05$.

\subsubsection{Habitat associations}

A Chi-squared goodness-of-fit test was used to assess whether echinoids followed an expected distribution pattern within available habitats, hence identifying whether a preference exists for certain habitats. If echinoids have a random association with habitat typologies then their observed numbers should be proportional to the relative amount of habitat observed. As such, expected numbers of echinoids were obtained from the habitat survey and observed frequencies were obtained from the number of echinoids surveyed. For example, the expected probability $\left(\mathrm{P}_{\mathrm{Exp}}\right)$ of observing a species in a certain habitat is 
the ratio of the amount (in $\mathrm{m}^{2}$ ) of that habitat observed over the sum of the area of all habitats present (equation 2). The expected count of each taxon was obtained by multiplying the expected probability for the taxon by the total number of observations made for the particular taxon (i.e. all habitats combined).

$$
\mathrm{P}_{\text {Exp }}(\text { Taxon } \mathrm{X})=\frac{\text { Total area of habitat } \mathrm{A}}{\sum \text { all habitats }}
$$

Since transect areas were of unequal size, all transects were standardized to 1000 $\mathrm{m}^{2}$ (for Australian and New Zealand study areas) and $5000 \mathrm{~m}^{2}$ (for the French study area) to make counts comparable across transects. Average observed counts per area were calculated for each habitat type and species.

Chi-squared goodness of fit tests were subsequently used to explore the association between echinoids and specific habitats. Where observed counts for echinoids were less than five, Yates continuity correction was applied to prevent overestimation of statistical significance for the small sample size (Yates, 1934).

\subsubsection{Habitat-related variables influencing echinoid distribution}

Six variables that may influence habitat use and distribution of echinoids were used for this analysis. These were the presence of other echinoids and predators (fish, octopi, decapod), water depth, geomorphology (seamount vs. slope for Australian study area only), distance to nearest seamount, and fishing history (fished vs. unfished). Splitting the predator factor up by predator type, we used the resulting 8 variables as predictors of spatial distribution in a binomial general linear mixed model (GLMM); they were set as fixed factors. Two additional factors were put into the model: seamount and image area. 'Seamount' identifies transects conducted on the same seamount; this random factor was to account for spatial autocorrelation. The image area was set as an exposure variable to offset the differing area of images, as the presence/absence of echinoids was used as a response variable. The GLMM was performed with package 'MASS' (Venables and Ripley, 2002) and 'nlme' (Pinheiro et al., 2014). This analysis was only performed on 
data from the Australian and New Zealand study areas, as there was insufficient information from the French study area about the habitat-related variables.

\section{Results}

\subsection{Habitat associations for class Echinoidea}

A total of 3,186 echinoids were observed in the French, 1,949 in the Australian, and 143 in the New Zealand study area. As a single taxonomic group, echinoids were found to use all habitats available to them (Table 3). In the French study area echinoids exhibited a random spatial distribution with available habitats $\left(\mathrm{df}=8, \chi^{2}=12.860, \mathrm{P}=0.1\right)$ meaning that echinoids were found in most habitats in proportions similar to the amount of habitats available to them. In contrast, echinoids in the Australian study area had a highly significant non-random spatial distribution with available habitats $\left(\mathrm{df}=9, \chi^{2}=169.304, \mathrm{P}\right.$ $<0.001)$. Insufficient data prevented determination of such statistics for the New Zealand study area. In all study areas, echinoids were most often observed in images containing living coral framework, consisting of $57 \%, 70 \%$, and $43 \%$ of observations in the French, Australian, and New Zealand study areas, respectively (Table 3). In the French region, living and loosely-packed CWC reefs, and their remains had the highest occupancy (14$20 \%$ ) out of nine habitats observed. In spite of this echinoids had a significant negative association with loosely-packed CWC reefs (Table 3). They were relatively equally distributed among the rest of habitats found at French sites. In the Australian study area, living and colonized CWC reefs had the highest occupancy (21-22\%) out of the 16 habitats observed. These two habitats alone accounted for more than $40 \%$ of habitat occupancy by echinoids in the study overall, and had a highly significant positive association with these two habitats (Table 3$)$. Infrequent observations $(\leq 11 \%)$ were made in the other habitats. Echinoids in the Australian study area had a significant negative association for bedrock, remains, and rubble habitats (Table 3). In the New Zealand study area, living and dead CWC reefs had the highest occupancy (19-24\%), followed by the bedrock habitat $(16 \%)$. Echinoids were equally and rarely $(\leq 7 \%)$ spread over the other ten habitats observed (Table 3). 
Table 3. Habitat distribution and associations of the Echinoidea -as a single taxonomic group- and specific taxon among living, dead and non-living habitats in canyons in the Bay of Biscay off France (F); the 'Tasman Fracture' and 'Huon' CMRs south of Tasmania, Australia (Aus); and 'Graveyard seamount complex' east of New Zealand (NZ). Expected counts $<5$ were not considered in chi-squared goodness of fit tests, which generated NAs (Not Applicable) for chi-square $p$ values. Results from chi-squared tests are displayed in the table ( $\mathrm{Df}=1 ; \mathrm{P}<0.05$ ). Only those taxa and study areas provided had sufficient numbers to conduct chi-squared tests. Cells left blank refer to habitats devoid of the particular taxon. Grey shaded cells indicate habitats that were not observed in the study area specified.

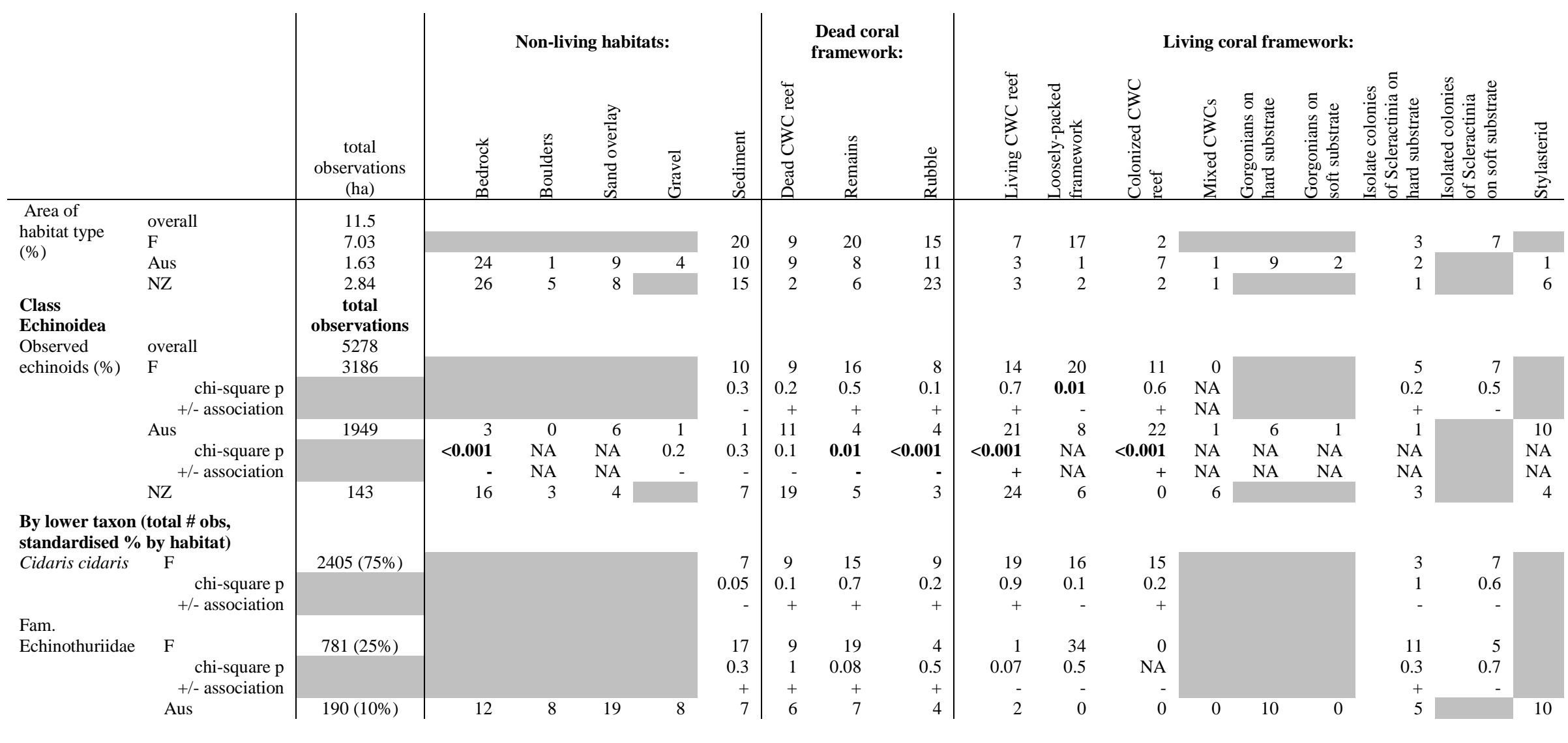




\begin{tabular}{|c|c|c|c|c|c|c|c|c|c|c|c|c|c|c|c|c|c|c|}
\hline & $\mathrm{NZ}$ & $60(42 \%)$ & 33 & 7 & 5 & & 30 & 2 & 8 & 13 & 0 & 0 & 2 & 0 & & & 0 & 0 \\
\hline $\begin{array}{l}\text { Dermechinus } \\
\text { horridus }\end{array}$ & Aus & $1129(58 \%)$ & 1 & & 0 & 0 & 0 & 14 & 3 & 2 & 30 & 11 & 30 & 1 & 7 & 2 & 0 & 0 \\
\hline & chi-square $p$ & & 0.1 & NA & NA & NA & NA & 0.8 & 0.08 & 0.04 & $<0.01$ & 0.1 & 0.8 & 1 & 1 & 0.6 & NA & NA \\
\hline & +/- association & & - & NA & NA & NA & NA & - & - & - & + & + & + & - & + & + & NA & NA \\
\hline $\begin{array}{l}\text { Caenopedina } \\
\text { otagoensis } \\
\text { Echinus }\end{array}$ & Aus & $281(14 \%)$ & 6 & 0 & 28 & 0 & 0 & 1 & 5 & 7 & 0 & 0 & 0 & 4 & 0 & 0 & 0 & 50 \\
\hline $\begin{array}{l}\text { multidentatus } \\
\text { Histocidaris }\end{array}$ & Aus & $143(7 \%)$ & 13 & 0 & 14 & 10 & 10 & 2 & 1 & 7 & 10 & 0 & 6 & 1 & 17 & 0 & 9 & 0 \\
\hline $\begin{array}{l}\text { purpurata } \\
\text { Caenopedina }\end{array}$ & Aus & $9(<1 \%)$ & 12 & 0 & 0 & 5 & 0 & 0 & 0 & 0 & 0 & 0 & 0 & 0 & 8 & 0 & 0 & 76 \\
\hline porphyrogigas & Aus & $197(9 \%)$ & 0 & 0 & 0 & 0 & 0 & 15 & 3 & 31 & 8 & 3 & 32 & 0 & 8 & 0 & 0 & 0 \\
\hline & $\mathrm{NZ}$ & $68(48 \%)$ & 3 & 2 & 0 & & 0 & 29 & 4 & 0 & 37 & 10 & 0 & 10 & & & 5 & 0 \\
\hline Cidaroidea & $\mathrm{NZ}$ & $15(10 \%)$ & 39 & 0 & 19 & & 0 & 0 & 5 & 0 & 14 & 0 & 0 & 0 & & & 0 & 23 \\
\hline
\end{tabular}




\subsection{Taxon-specific habitat associations}

Six species of echinoids and two higher taxon groups that could not be resolved further were observed in images from the three study areas (Table 3). Only two of the taxa were observed in more than one study area: the unresolved family group Echinothuriidae (three study areas); and Caenopedina porphyrogigas (for Australia and New Zealand study areas) (Table 3). The Australian region was the most diverse with six taxa; although clearly dominated by Dermechinus horridus (58\% of total observations). The New Zealand region comprised three taxa, two of which, C. porphyrogigas and the family group Echinothuriidae contributed near-equally ( $48 \%$ and $42 \%$, respectively) to the total observations. The French region was the least diverse with only two taxa, clearly dominated by Cidaris cidaris ( $75 \%$ of total observations) (Table 3).

Quantitative comparative analyses were only possible for the data available on echinothuriids and C. cidaris observed in French study area; and D. horridus observed in Australian study area. In the overall test, $C$. cidaris had a random association with respect to habitats available ( $\mathrm{df}=8, \chi^{2}=11.272, \mathrm{P}=0.2$ ), while $D$. horridus and echinothuriids exhibited a significant non-random association with available habitats $(D$. horridus: $\mathrm{df}=$ $4, \chi^{2}=10.986, \mathrm{P}=0.03$; echinothuriids: $\mathrm{df}=5, \chi^{2}=12.584, \mathrm{P}=0.03$ ).

Taxon-level analyses showed that some taxa were found in certain habitats but were absent from others. $D$. horridus was mostly found in living coral framework habitats (81\% of observations), with a strong and significant association with living CWC reefs (30\% of observations; $\mathrm{df}=1, \chi^{2}=6.724, \mathrm{P}<0.01$ ) and a positive but non-significant association with colonized CWC reefs (Table 3). This species was also found in looselypacked CWC reef and gorgonian (on hard substrate) habitats, but rarely in gorgonian (on soft substrate) and mixed CWC habitats. Most (14\%) D. horridus observations were made in dead CWC reefs, but the species was rarely found in rubble, remains and bedrock habitats. A significant negative association was observed between $D$. horridus and rubble as well as a negative but non-significant association with the other non-living habitats and dead coral framework (Table 3).

Echinus multidentatus was encountered in all three high level habitat types observed (Table 3). Within the living coral framework habitats E. multidentatus was mostly observed in gorgonian (on hard substrate) habitats (17\%). It was also found in 
slightly lower numbers in colonized and living CWC reefs ( 7 and $10 \%$, respectively). In non-living habitats it was found in relatively similar numbers among bedrock, sand overlay, gravel, and sediment habitats (10-14\%). A small number of observations were recorded in the dead coral habitats.

C. otagoensis was most frequently observed in living coral framework habitats, and this was mainly due to the high frequency of observations (50\%) in stylasterid habitats (Table 3). The species was also frequently observed in sand overlay habitats and to a lesser extent in bedrock, mixed CWC reefs, rubble, and remains habitats.

Cidaroidea were rarely observed in the New Zealand study area, but when encountered, these echinoids were primarily found in non-living habitats, such as bedrock and sand overlay, and in living coral infrastructure, stylasterid and living CWC reef habitats (Table 3).

Similar to cidaroids patterns on New Zealand seamounts, $H$. purpurata in the Australian study area were most often associated with stylasterid and bedrock habitats. This species, along with echinothuriids, cidaroid, and C. otagoensis, were the only taxa observed among stylasterids (Table 3).

Caenopedina porphyrogigas was encountered in the Australian and New Zealand study areas, and general patterns of habitat association were similar in both study areas. C. poryphyrogigas was almost exclusively observed in images containing living and dead coral infrastructure and observations in non-living habitats were rare $(<1 \%$ total in the Australian and $<5 \%$ in the New Zealand; Table 3). In the Australian study area, the species were evenly distributed between living and dead coral infrastructure while there was an indication of an association with living coral infrastructure (consisting of $62 \%$ of observations) in the New Zealand study area.

Habitats available to $C$. cidaris and echinothuriids in the French study area differed slightly from those available in the two SW Pacific study areas. In NE Atlantic, there were few non-living types of habitats observed; only sediment habitat types were encountered in this broad habitat category. $C$. cidaris were most often observed on living CWC reefs; favouring living, loosely-packed, and colonized CWC reefs $(15-19 \%$ of observations), but were also observed among isolated coral colonies (Table 3). C. cidaris were found in dead coral framework and non-living habitats, they were found in sediment 
as often as in isolated colonies and had a fairly even distribution between coral remains, rubble and dead CWC reef (9-15\%). Chi-squared tests did not reveal significant associations with any of these habitats (Table 4).

In the SW Pacific, echinothuriids were most frequently encountered in non-living habitats, making up about $54 \%$ and $75 \%$ of observations at Australian and New Zealand sites, respectively (Table 3). Of these habitats, echinoids were most often observed in sand overlay and bedrock habitats (12-19\%) in the Australian study area, and similarly, sediment and bedrock habitats (30-33\%) in the New Zealand study area. In the living coral framework habitats, echinothuriids were only observed among gorgonians (on hard substrate), stylasterid, isolated colonies of scleractinians, and rarely (2\%) in living and colonized CWC reef habitats. Echinothuriids in the French study area were most often observed in living coral framework habitats (Table 3); this was mostly owing to their strong association with loosely-packed CWC reefs (34\%) and isolated colonies of scleractinians (16\% combined). Echinothuriids were also found in high density in sediment and coral remains habitats (17 and 19\% of observations, respectively), and to a lesser extent among rubble (4\%), dead (9\%) and living CWC reefs (1\%). Chi-squared tests did not reveal significant associations with the habitats available to echinothuriids (Table 2).

\subsection{Habitat-related variables influencing echinoid distribution}

Five of the eight variables examined were significantly related to the distribution of at least one echinoid taxon (Table 4). Depth and the presence of interspecific competitors were the most influential variables, each significantly related to the occurrence of five of the six taxa examined. Surprisingly, where the same taxon was examined for the Australian and New Zealand study areas the results were not matched. Depth was significantly correlated with the distribution of $C$. porphyrogigas and Echinothuriidae in the New Zealand, but not in the Australian, study area; this result was reversed for the

presence of interspecific competitors (Table 4). Fishing history was significantly correlated with distribution of four taxa with matching significant results for Echinothuriidae from the Australian and New Zealand regions (Table 4). The presence of fish predators was significantly related to the distribution of Echinothuriidae, but only in 
the Australian study area, while geomorphology had a significant effect on the distribution of $D$. horridus. 
Table 4. Habitat-related variables related to echinoid distribution in the 'Tasman Fracture Zone' and 'Huon' area, south of Tasmania, Australia (Aus); and the 'Graveyard complex seamounts', east of New Zealand (NZ). Results from the binomial generalized linear mixed effects model (GLMM) are displayed (P < 0.05). NA - Not applicable.

\begin{tabular}{|c|c|c|c|c|c|c|c|c|}
\hline & \multirow{2}{*}{$\begin{array}{c}\text { C. otagoensis } \\
\text { (Aus) }\end{array}$} & \multirow{2}{*}{$\begin{array}{l}\text { E. multidentatus } \\
\text { (Aus) }\end{array}$} & \multirow{2}{*}{$\begin{array}{l}\text { D. horridus } \\
\text { (Aus) }\end{array}$} & \multicolumn{2}{|c|}{ C. porphyrogigas } & \multicolumn{2}{|c|}{ Echinothuriidae } & \multirow{2}{*}{$\begin{array}{c}\text { Cidaroidea } \\
\text { (NZ) }\end{array}$} \\
\hline & & & & (Aus) & $(\mathrm{NZ})$ & (Aus) & $(\mathrm{NZ})$ & \\
\hline $\begin{array}{r}\text { Interspecific } \\
\text { competitor }\end{array}$ & $<0.001$ & $<0.001$ & $<0.001$ & $<0.001$ & 1 & $<0.001$ & 1 & 1 \\
\hline Fish predator & 0.7 & 0.6 & 0.1 & 0.6 & 1 & 0.02 & 1 & 1 \\
\hline Decapod predator & 0.1 & 0.2 & 0.08 & 0.3 & 1 & 0.1 & 1 & 1 \\
\hline Octopus predator & 1 & 1 & 1 & 1 & NA & 1 & NA & NA \\
\hline Depth & $<0.001$ & $<0.001$ & $<0.001$ & 0.9 & $<0.001$ & 0.09 & 0.01 & 0.8 \\
\hline Geomorphology & 0.2 & 0.9 & 0.02 & 0.5 & NA & 0.7 & NA & NA \\
\hline Distance to seamount & 074 & 0.7 & 0.9 & 0.6 & 0.06 & 0.2 & 0.5 & 0.6 \\
\hline Fishing history & 0.4 & 0.03 & $<0.001$ & 0.1 & $<0.001$ & 0.04 & 0.003 & 0.6 \\
\hline
\end{tabular}




\section{Discussion}

\subsection{Distribution of echinoids in CWC habitats}

Patterns of habitat usage varied widely among echinoid taxa; some species, such as Cotagoensis, H. purpurata, and D. horridus, favoured specific habitats over others and taxa, such as $C$. porphyrogigas, E. multidentatus, cidaroids, and echinothuriids, used a wider variety of habitats. In some cases, there were large overlaps in habitat usage with sympatric taxa.

C. otagoensis and $H$. purpurata were primarily distributed among stylasterid habitats, which mostly occur on bedrock in the surveyed areas, and were rarely found in more complex habitats. This apparent distribution in relatively simple habitats on hard substrates suggests a possible preference for uniform hard bottom type habitats over complex and soft bottom ones. Previous studies in shallow-water habitats have demonstrated a close physical linkage between echinoids and habitat substrata (McClanahan and Kurtis, 1991; McClanahan and Muthiga, 2001; Dumas et al., 2007). This apparent preference is likely linked to habitat impacts on echinoid feeding and locomotory behaviour, as well as shelter availability.

Alternatively, in the case of $C$. otagoensis, the absence of this species from more complex habitats might be attributed to its relatively small size (diameter size of 15-40 $\mathrm{mm}$; Tracey et al., 2011) and/or an aversion to structurally complex habitats. It is possible that the species associates with living infrastructure, but it might not have been detected in the study because small taxa are harder to detect in photographic surveys especially since they can be hidden within the coral matrix. However, it is important to note its absence from gorgonian, isolated colonies, and loosely-packed frameworks as well. The species would have been more conspicuous in these habitats due to the relatively sparse infrastructure, which is consistent with the idea of a possible aversion for structurally complex habitats.

Hart and Chia (1990) found size-related differences in food requirements in laboratory experiments conducted on Echinometra mathaei. Given the tendency for echinoids to optimize their energy intake by preferentially feeding on nutrient-rich foods over lower quality foods (Lyons and Scheibling, 2007), as well as the added benefit of 
protection afforded by dense coral infrastructure, the absence of $C$. otagoensis and $H$. purpurata from infrastructure-rich living and dead coral framework habitats remains an anomaly that warrants further investigation.

D. horridus was primarily distributed among dense living coral infrastructure; this preference is likely linked to its mode of feeding. A pronounced vertical elongation of the corona and modified secondary spines observed in D. horridus has led echinoderm scientists to propose a suspension mode of feeding for this species (Fell, 1976; Kroh, 2012). This theory has not yet been tested, but suspension-feeding has already been described in four other echinoid taxa (e.g. Dendraster, Echinostrephus, Echinometra and Evechinus in Kroh, 2012). While coral infrastructure may not be a direct source of food for $D$. horridus, its elevated habitat may facilitate the capture of organic particles and reduce sediment particle obstructions by placing $D$. horridus in swifter currents. As well, its absence from, or rare occurrence in, non-complex habitats (e.g. sand overlay, sediment, bedrock, etc) is consistent with the proposed mode of feeding.

In the Australian study area, $C$. porphyrogigas had a similar distribution to that of $D$. horridus, but unlike $D$. horridus it was also frequently distributed in coral rubble. As such, this species' co-occurrence with coral reef-building type localities might be attributed to food resources provided by the live and dead coral infrastructure as well as its broken fragments rather than the corals ability to provide elevation into the water column (as needed by $D$. horridus).

No strong habitat associations were detected for E. multidentatus and echinothuriids at Australian sites. Here, both taxa were widespread and evenly distributed across all habitats available to them suggesting generalist habitat utilization. This generalist approach by E. multidentatus was surprising as it possesses a similar test morphology to C. porphyrogigas (see Tracey et al., 2011 for dimensions), which suggests that a factor other than morphology might be restricting E. multidentatus exploitation of living coral habitats. Under food-limited conditions, inter- and intraspecific competition is frequently observed among shallow-water echinoids (Sammarco, 1980; McClanahan, 1988; Shulman, 1990; McClanahan, 1992; Privitera et al., 2008). Experimental trials have revealed competition between Echinometra lucunter (Linnaeus, 1758) and Echinometra viridis, which commonly engaged in antagonistic interactions between conspecifics and 
congeners (Shulman, 1990). Encounters result in pushing, biting, and subsequent conquer of a location after displacement of another individual (Shulman, 1990). Identifying mechanisms underlying this relationship was beyond the present paper, but competitive hierarchy might serve as a possible hypothesis to explain the generalist approach of E. multidentatus. This species might occupy a wider range of habitats where more competitive taxa ( $D$. horridus and $C$. porphyrogigas in this case) are infrequently observed. Further work is necessary to determine the likely drivers of the distribution of E. multidentatus.

Data from the Australian and New Zealand study areas permitted comparisons of patterns for habitat association in nearby localities with similar habitat typologies. For C. porphyrogigas, such comparisons revealed similarities in general patterns of habitat association. This regional consistency observed for C. porphyrogigas was further confirmed by patterns found among echinothuriids in the Australian and New Zealand study areas. While bedrock and sediment habitats in the New Zealand study area were disproportionately favoured over other habitats for this taxon, the vast majority of echinothuriids in both study areas were generally distributed within these non-living habitats thus suggesting consistency in the overall pattern of habitat association observed in nearby regions. However, patterns did not appear to hold over a broad geographic scale (NE Atlantic vs. SW Pacific) as echinothuriids in the French study area appeared to mostly associate with live coral infrastructure. This finding may be due to the fact that habitats available in the canyons of the French study area differed greatly from those available on the slope and seamounts in the SW Pacific study area. In the French study area, there were few non-living types of habitats observed. This result suggests that habitat preferences might differ given the different habitats available to them. However, quantitative analysis, albeit not statistically significant, revealed a negative association with this habitat. Thus highlighting the fact that quantitative assessment can reveal habitat preferences that are not apparent with qualitative analysis.

Despite the overarching differences observed in the mode of habitat utilization, some similarities were apparent over a broad geographic scale (NE Atlantic vs. SW Pacific). In all study areas, echinothuriids were consistently found in similar densities across dead CWC reefs, remains and rubble habitats, but rarely or never found in dense 
living habitats, such as living CWC reefs, dead CWC reefs, colonized CWC reefs, and mixed CWC habitats. Morphology is known to affect the habitat use potential of echinoids (Hill and Lawrence 2003; Coppard and Campbell 2005) and can help estimate the mode of living of echinoids (Fell, 1976). It is possible that the flexible test of echinothuriids might prevent the exploitation of dense coral habitats as the coral infrastructure can perforate the soft corona of the echinothuriid (A. Stevenson personal observation) hence its restriction to non-living habitats, rubble, remains, and habitats that are sparsely packed, such as isolated colonies, stylasterid habitat types and ideally loosely-packed CWC reefs.

\subsection{Exploring relationships between echinoid taxa distributions and habitat-related} predictor variables

The presence of other echinoid species, depth, and fishing history influenced taxa distribution patterns most strongly. The importance of competition in structuring echinoid distribution patterns has been observed previously in shallow water habitats (McClanahan, 1988; Privitera et al, 2008), but no studies have previously considered this factor for deep-sea species. However, several studies have proposed that the high diversity of deep-sea echinoderms is a result of the reduction or avoidance of competitive interactions in echinoderm communities through specialized feeding strategies (Billett et al., 1988; Jumars et al., 1990; Iken et al., 2001; Hudson et al., 2003; Wigham et al., 2003; Hudson et al., 2004). Differential habitat exploitation by echinoid taxa observed by the present study might contribute to reduced competitive interactions, and the therefore the identification of the presence of a competitor as an important variable in the correlation analysis.

Depth had a significant impact on the distribution of $C$. otagoensis, $E$. multidentatus, and D. horridus. A significant relationship was also detected for $C$. poryphyrogigas and Echinothuriidae, but only in the New Zealand study area. Depth might restrict echinoid distribution and their depth distribution might align with that of coral habitats, but it is unlikely that habitat utilization is related to this factor.

The effect of fishing history varied by species: C. otagoensis, C. porphyrogigas (in the Australian study area), and the Cidaroidea (in the New Zealand study area) 
occurred without bias at trawled and untrawled sites; D. horridus, E. multidentatus, and C. porphyrogigas (in the New Zealand study area) were more often and significantly associated with unfished sites; while echinothuriids in both regions displayed an affinity with trawled sites. Similar taxa segregation between trawled and untrawled sites were described by Althaus et al. (2009) and Williams et al. (2010) who found large differences in megabenthos assemblage composition between trawled and untrawled sites; there was a higher abundance of sea urchins, crinoids, gorgonians, and chrysogorgid corals in trawled sites. Benthic trawling physically removes or breaks up the coral infrastructure thereby changing the habitats available, which explains the variable effect of fishing history on different echinoid taxa.

The lack of significant predator influence on the distribution of all echinoids except the echinothuriids was not consistent with previous findings that predation risk played a strong role in structuring echinoid space and resource use within habitats containing coral infrastructure (Stevenson et al., 2014). However, although it didn't include echinoids, Bell and Westoby (1986) found habitat preference, rather than predation, to be the dominating factor explaining general macrofaunal distributions in seagrass beds. While predation might influence usage of structural components within a habitat (e.g. positioning on coral infrastructure), it does not appear to influence distribution patterns across the habitats themselves.

\subsection{Comparing distributions at a different taxonomic resolution: class Echinoidea vs. species level}

When using a generalised class level approach, species-specific details of habitat associations were lost as they became masked by patterns of the dominant taxa in the region. As a result patterns of habitat distribution and association observed at a broader taxonomic resolution were very different from those observed at a finer resolution. As a whole the Echinoidea were found in all habitats and, where quantitative analyses were possible, significant associations were found for bedrock, remains, rubble as well as living coral frameworks. The opposite was true when analysing the data at a finer resolution: the Echinoidea in the French study area were generalist in their habitat use. This information was reflective of the generalist approach utilized by the dominant 
echinoid, C. cidaris, but it failed to detect the specialized habitat association of echinothuriids. Similarly, patterns of habitat use by the broader taxonomic group in the Australian study area were consistent with that of the dominant taxon, D. horridus. However, D. horridus has a strong association with living and colonized CWC reefs, which masked the preference of the other taxa in the region; most of which did not associate with live coral infrastructure.

In both French and Australian study areas, it was apparent that the specialized habitat requirements of some species were not recognized nor was the breadth of habitats utilized by the various species in each region. Such losses in resolution can lead to commission (where a species is mistakenly thought to be present) and omission (where a species is mistakenly thought to be absent) errors (Rondinini et al 2006) and in the case of taxa that have specific impacts on coral ecosystems it could lead to erroneous conclusions about that ecosystem (Sammarco, 1982). It is therefore important to consider taxonomic resolution when conducting deep-sea ecological research, especially when applying habitat preference results to conservation planning.

\section{Conclusions}

Patterns of habitat usage varied widely among echinoid taxa; some species, such as $C$. otagoensis, H. purpurata, and D. horridus, favoured specific habitats, whereas others such as C. porphyrogigas, E. multidentatus, cidaroids, and echinothuriids, used a wider variety of habitats. In some cases, there were large overlaps in habitat usage with sympatric taxa. Not all taxa showed preference for matrix-forming coral habitats, despite increased shelter offered from predators. Echinoid population structure was significantly influenced by the presence of other echinoids, depth, and fishing history, which are variables that are in part related to habitat.

Patterns in echinoid habitat association held regionally (Australian vs. New Zealand study area), but differed at a broader geographic scale (SW Pacific vs. NE Atlantic study areas). While patterns may be reasonably extended to reflect those of nearby regions this is not advisable for broader geographic scale, especially for those regions where available coral habitats may differ because they are within different broader habitats (i.e. canyons vs. seamounts). More widespread, as well as intensive, and 
comparable sampling is required to address broader geographical patterns of coral habitat associations for echinoids.

Video and still image data can be a powerful tool to detect trends in echinoid habitat associations. Refinement of the methods are required to improve quantitative analyses of habitat associations, but it is clear that such taxon-specific studies, conducted at a more precise taxon and habitat scale, are necessary. Most deep-sea ecological studies to date have been conducted at a wider resolution (e.g. taxon class Echinoidea, and habitat categories 'seamount', 'continental slope'), which may not be the most appropriate scale to be useful for the proper ecological understanding and subsequent spatial management planning for vulnerable deep-sea habitats such as coral reefs.

\section{Acknowledgements}

We thank the pilots of the ROV Victor 6000 and operators of the towed cameras, as well as the captain and crew of 'NO Pourquoi Pas?', ' $R V$ Tangaroa', and 'FRV Southern Surveyor' for their support in seagoing operations. Thanks are also due to Owen Anderson (NIWA) for valuable assistance with SW Pacific echinoid taxonomy and biology; Peter McMillan (NIWA) for providing fish identifications; Tadhg O Corcora for help processing the large datasets; and Professor Myra O'Regan (TCD) for statistical advice. This study was partly funded by the Irish Research Council EMBARK postgraduate scholarship to A. Stevenson and by the EC FP7 project 'CoralFISH' [grant agreement no. 213144]. The New Zealand Ministry of Primary Industries and Ministry of Business, Innovation and Employment funded NIWA to obtain data from the Graveyard Seamount Complex (and supported some time for MRC, DAB and AAR), and the Australian Government Department of Water, Environment, Heritage and the Arts and CSIRO Wealth from Oceans Flagship funded staff from Australia's Marine National Facility (including FA and AW).

\section{References}

Althaus, F., Williams, A., Schlacher, T., Kloser, R., Green, M., Barker, B., Bax, N., Brodie, P., \& Schlacher-Hoenlinger, M. (2009). Impacts of bottom trawling on deep-coral 
ecosystems of seamounts are long-lasting. Marine Ecology Progress Series, 397, 279294.

Bak, R. (1994). Sea urchin bioerosion on coral reefs: place in the carbonate budget and relevant variables. Coral Reefs, 13, 99-103.

Bell, D.J., \& Westoby, M. (1986). Variation in seagrass height and density over a wide spatial scale: effects on common fish and decapods. Journal of Experimental Marine Biology and Ecology, 104, 275-295.

Billett, D., Llewellyn, C., \& Watson, J. (1988). Are deep-sea holothurians selective feeders. Echinoderm Biology (eds R.D. Burke, P.V. Mladenov, P. Lambert, \& R.L. Parsley), pp. 421-429, Balkema, Rotterdam.

Bo, M., Bertolino, M., Borghini, M., Castellano, M., Harriague, A.C., Di Camillo, C. G., Gasparini, G., Misic, C., Povero, P., \& Pusceddu, A. (2011). Characteristics of the mesophotic megabenthic assemblages of the Vercelli seamount (North Tyrrhenian Sea). PLoS ONE, 6, e16357.

Bromley, R. (1978). Bioerosion of Bermuda reefs. Palaeogeography, Palaeoclimatology, Palaeoecology, 23, 169-197.

Calenge, C. (2007). Exploring habitat selection by wildlife with adehabitat. Journal of statistical software, 22, 2-19.

Cartes, J.E., Maynou, F., Fanelli, E., Romano, C., Mamouridis, V., \& Papiol, V. (2009). The distribution of megabenthic, invertebrate epifauna in the Balearic Basin (western Mediterranean) between 400 and $2300 \mathrm{~m}$ : Environmental gradients influencing assemblages composition and biomass trends. Journal of Sea Research, 61, 244-257.

Clark, M.R., \& Rowden, A.A. (2009). Effect of deepwater trawling on the 
macroinvertebrate assemblages of seamounts on the Chatham Rise, New Zealand. Deep Sea Research I, 56, 1540-1554.

Clark, M.R., Rowden, A.A., Schlacher, T., Williams, A., Consalvey, M., Stocks, K.I., Rogers, A.D., O'Hara, T.D., White, M., \& Shank, T.M. (2010a). The ecology of seamounts: structure, function, and human impacts. Annual Review of Marine Science, 2, 253-278.

Clark, M.R., Bowden, D.A., Baird, S.J., Stewart, R. (2010b). Effects of fishing on the benthic biodiversity of seamounts of the "Graveyard" complex, northern Chatham Rise. New Zealand Aquatic Environment and Biodiversity Report No. 46.40 p.

Clark, M.R., Anderson, O., Bowden, D., Chin, C., George, S., Glasgow, D., Guinotte, J., Hererra, S., Osterhage, D., Pallentin, A., Parker, S., Rowden, A.A., Rowley, S., Stewart, R., Tracey, D., Wood, S., Zeng, C. (2014). Vulnerable Marine Ecosystems on the Louisville Seamount Chain: voyage report of a survey (TAN1402) in February 2014. New Zealand Aquatic Environment and Biodiversity Report. (in press)

Connell, J., \& Jones, G.P. (1991). The influence of habitat complexity on postrecruitment processes in temperate reef fish population. Journal of Experimental Marine Biology and Ecology, 151, 271-294.

Coppard, S.E., \& Campbell, A.C. (2005). Distribution and abundance of regular sea urchins on two coral reefs in Fiji. Micronesica, 37, 249-269.

Dotan, A. (1990). Distribution of regular sea urchins on coral reefs near the south-eastern tip of the Sinai Peninsula, Red Sea. Israel Journal of Zoology, 37, 15-29.

Dumas, P., Kulbicki, M., Chifflet, S., Fichez, R., \& Ferraris, J. (2007). Environmental factors influencing urchin spatial distributions on disturbed coral reefs (New Caledonia, South Pacific). Journal of Experimental Marine Biology and Ecology, 344, 88-100. 
Dunstan, P.K., Althaus, F., Williams, A., \& Bax, N.J. (2012). Characterising and predicting benthic biodiversity for conservation planning in deepwater environments. PLoS ONE, 7, e36558.

Etnoyer, P., \& Morgan, L.E. (2005). Habitat-forming deep-sea corals in the Northeast Pacific Ocean. Cold-water Corals and Ecosystems (eds Freiwald, A., \& Roberts, J.M.), pp. 331-343, Springer-Verlag Berlin Heidelberg.

Fell, F.J. (1976). The Cidaroida (Echinodermata: Echinoidea) of Antarctica and the Southern Oceans. A thesis submitted in partial fulfilment of the requirements for the Degree of Doctor of Philosophy (in Zoology). The Graduate School of Maine at Orono. 294 pp.

Freiwald, A., Fossâ, J., Grehan, A., Koslow, T., \& Roberts, J. (2004). Cold-water coral reefs. UNEP-WCMC, Cambridge, UK.

Gage, J., \& Tyler, P. (1992). Deep-sea biology: a natural history of organisms at the deep-sea floor. Cambridge, Cambridge University Press.

Glynn, P., Wellington, G., \& Birkeland, C. (1979). Coral reef growth in the Galapagos: limitation by sea urchins. Science, 203, 47.

Glynn, P.W. (1997). Bioerosion and coral-reef growth: a dynamic balance. Life and death of coral reefs (ed. C. Birkeland), pp. 68-95, Chapman \& Hall, New York.

Guillaumont B, Tempera F, Davies, J. *, Vertino A, Beuck, L, Ólafsdóttir S H, Smith C, Fossa J H, Van Den Beld I, Savini, A, Rengstorf A, Grehan, A. 2016. CoralFISH Northeast Atlantic andMediterranean Cold-Water Coral Habitats Catalogue. DOI: https://doi.org/10.5281/zenodo.580684 
Hart, L.J., \& Chia, F-S. (1990). Effect of food supply and body size on the foraging behaviour of the burrowing sea urchin Echinometra mathaei (de Blainville). Journal of Experimental Marine Biology and Ecology, 135, 99-108.

Heithaus, M.R., Hamilton, I.M., Wirsing, A.J., \& Dill, L.M. (2006). Validation of a randomization procedure to assess animal habitat preferences: microhabitat use of tiger sharks in a seagrass ecosystem. Journal of Animal Ecology, 75, 666-676.

Henry, L.-A., \& Roberts, J.M. (2007). Biodiversity and ecological composition of macrobenthos on cold-water coral mounds and adjacent off-mound habitat in the bathyal Porcupine Seabight, NE Atlantic. Deep Sea Research Part I: Oceanographic Research Papers, 54, 654-672.

Hill, S.K., \& Lawrence, J.M. (2003). Habitats and characteristics of the sea urchins Lytechinus variegatus and Arbacia punctulata (Echinodermata) on the Florida GulfCoast Shelf. Marine Ecology, 24, 15-30.

Hill P. (2009) Designing a Deep-Towed Camera Vehicle Using Single Conductor Cable. Sea Technology 50 (12), 49-51.

Howell, K.L., Billett, D.S.M., \& Tyler, P.A. (2002). Depth-related distribution and abundance of seastars (Echinodermata: Asteroidea) in the Porcupine Seabight and Porcupine Abyssal Plain, NE Atlantic. Deep Sea Research Part I: Oceanographic Research Papers, 49, 1901-1920.

Howell, K.L., Heymans, J.J., Gordon, J.D.M., Duncan, J., Ayers, M., Jones, E.G. 2009. DEEPFISH Project: Applying an ecosystem approach to the sustainable management of deep-water fisheries. Part 1: Development of the Ecopath with Ecosim model. Scottish Association for Marine Science, Oban. U.K. 
Hudson, I., Wigham, B., Billett, D., \& Tyler, P. (2003). Seasonality and selectivity in the feeding ecology and reproductive biology of deep-sea bathyal holothurians. Progress in oceanography, 59, 381-407.

Hudson, I., Wigham, B., \& Tyler, P. (2004). The feeding behaviour of a deep-sea holothurian, Stichopus tremulus (Gunnerus) based on in situ observations and experiments using a Remotely Operated Vehicle. Journal of Experimental Marine Biology and Ecology, 301, 75-91.

Iken, K., Brey, T., Wand, U., Voigt, J., \& Junghans, P. (2001). Food web structure of the benthic community at the Porcupine Abyssal Plain (NE Atlantic): a stable isotope analysis. Progress in oceanography, 50, 383-405.

Jumars, P., Mayer, L., Deming, J., Baross, J. \& Wheatcroft, R. (1990). Deep-sea depositfeeding strategies suggested by environmental and feeding constraints. Philosophical Transactions of the Royal Society of London. Series A, Mathematical and Physical Sciences, 331, 85-101.

Khripounoff, A., Caprais, J.-C., Le Bruchec, J., Rodier, P., Noel, P., \& Cathalot, C. (2014). Deep cold-water coral ecosystems in the Brittany submarine canyons (Northeast Atlantic): Hydrodynamics, particle supply, respiration, and carbon cycling. Limnology and Oceanography, 59, 87-98.

Koike, I., Mukai, H., \& Nojima, S. (1987). The role of the sea urchin, Tripneustes gratilla (Linnaeus), in decomposition and nutrient cycling in a tropical seagrass bed. Ecological Research, 2, 19-29.

Kroh, A. (2012). "Are cactus urchins filter feeders? (Echinoidea: Dermechinus)." $14^{\text {th }}$ International Echinoderm Conference. The Royal Academy of Sciences of Belgium, Brussels, Belgium. Conference presentation. 
Lawrence, J.M. (1975). On the relationships between marine plants and sea urchins. Oceanography and marine Biology Annual Review, 13, 213-286.

Lyons, D.A., \& Scheibling, R.E. (2007). Effect of dietary history and algal traits on feeding rate and food preference in the green sea urchin Strongylocentrotus droebachiensis. Journal of Experimental Marine Biology and Ecology, 349, 194-204.

Mackay, K.A., Wood, B.A., Clark, M.R. (2005). Chatham Rise Bathymetry. NIWA Miscellaneous Chart Series No. 82. NIWA, Wellington.

McClanahan, T.R. (1988). Coexistence in a sea urchin guild and its implications to coral reef diversity and degradation. Oecologia, 77, 210-218.

McClanahan, T.R., \& Kurtis, J.D. (1991). Population regulation of the rock-boring seaurchin Echinometra mathaei (Deblainville). Journal of Experimental Marine Biology and Ecology, 147, 121-146.

McClanahan, T. (1992). Resource utilization, competition, and predation: a model and example from coral reef grazers. Ecological modelling, 61, 195-215.

McClanahan, T.R., \& Muthiga, N.A. (2001). The ecology of Echinometra. Edible Sea Urchins (ed. J.M. Lawrence), pp. 225-243, Elsevier, Amsterdam.

Miller, K., Williams, A., Rowden, A.A., Knoles, C., \& Dunshea, G. (2010). Conflicting estimates of connectivity among deep- sea coral populations. Marine Ecology, 31, 144157.

Miskelly, Ashley (2002). Sea urchins of Australia and the Indo-Pacific. Capricornica Publications, Sydney. 180 p.

Pinheiro, J., Bates, D., DebRoy, S., Sarkar, D., \& R Core Team (2014). nlme: Linear and 
Nonlinear Mixed Effects Models. R package version 3.1-117, URL: http://CRAN.Rproject.org/package $=$ nlme.

Privitera, D., Chiantore, M., Mangialajo, L., Glavic, N., Kozul, W., \& Cattaneo-Vietti, R. (2008). Inter-and intra-specific competition between Paracentrotus lividus and Arbacia lixula in resource-limited barren areas. Journal of Sea Research, 60, 184-192.

R Core Team (2013). R: A language and environment for statistical computing. $R$ Foundation for Statistical Computing, Vienna, Austria. URL http://www.R-project.org/.

Risk, M.J. (1972). Fish diversity on a coral reef in the Virgin Islands. Atoll Research Bulletin, 153, 1-6.

Rondinini, C., Wilson, K.A., Boitani, L., Grantham, H., \& Possingham, H.P. (2006). Tradeoffs of different types of species occurrence data for use in systematic conservation planning. Ecology Letters, 9, 1136-1145.

Sammarco, P.W. (1980). Diadema and its relationship to coral spat mortality: grazing, competition, and biological disturbance. Journal of Experimental Marine Biology and Ecology, 45, 245-272.

Sammarco, P.W. (1982). Echinoid grazing as a structuring force in coral communities: whole reef manipulations. Journal of Experimental Marine Biology and Ecology, 61, 3155.

Sauchyn, L., \& Scheibling, R. (2009). Degradation of sea urchin feces in a rocky subtidal ecosystem: implications for nutrient cycling and energy flow. Aquatic Biology, 6, 99-108.

Scheibling, R., \& Hamm, J. (1991). Interactions between sea urchins (Strongylocentrotus droebachiensis) and their predators in field and laboratory experiments. Marine Biology, $110,105-116$. 
Schultz, Heinke (2005). Sea-Urchins, a guide to worldw;de shallow water species. Heinke \& Peter Schultz Scientific Publications, Augsburg, Germany. 484 p.

Shulman, M. (1990). Aggression among sea urchins on Caribbean coral reefs. Journal of Experimental Marine Biology and Ecology, 140, 197-207.

Shortis, M.R., Seager, J.W., Williams, A., Barker, B.A. \& Sherlock, M. (2008) Using stereo-video for deep water benthic habitat surveys. Marine Technology Society Journal, 42(4), 28-37.

Stevenson, A., \& Rocha, C. (2013). Evidence for the bioerosion of deep-water corals by echinoids in the Northeast Atlantic. Deep Sea Research Part I: Oceanographic Research Papers, 71, 73-78.

Stevenson, A., Mitchell, F.J.G., \& Davies, J.S. (2015). Predation has no competition: factors influencing space and resource use by echinoids in deep-sea coral habitats, as evidenced by continuous video transects. Marine Ecology, 36(4), 1454-1467.

Stevenson, A., Mitchell, F (2016) Evidence of nutrient partitioning in coexisting deep-sea echinoids, and seasonal dietary shifts in seasonal breeders: Perspectives from stable isotope analyses. Progress in Oceanography, 141, 44-59.

Tracey DM, Anderson OF, Naylor JR (2011) A guide to common deepsea invertebrates in New Zealand waters. New Zealand Aquatic Environment and Biodiversity Report No. 86.317 p.

Van Oevelen, D., Duineveld, G., Lavaleye, M., Mienis, F., Soetaert, K., \& Heip, C. (2009). The cold-water coral community as a hot spot for carbon cycling on continental margins: A food-web analysis from Rockall Bank (northeast Atlantic). Limnology and Oceanography, 54, 1829-1844. 
Venables, W.N., \& Ripley, B.D. (2002). Modern Applied Statistics with S. Fourth Edition. Springer, New York. ISBN 0-387-95457-0

Walker, T.I., Stevens, J.D., Braccini, J.M., Daley, R.J., Huveneers, C., Irvine, S.B., Bell, J.D., Tovar-Avila, J., Trinnie, F.I., Philips, D.T., Treloar, M.A., Awruck, C.A., Gason, A.S., Salini, J., \& Hamlett, W.C. (2008). Rapid assessment of sustainability for ecological risk of shark and other chondrichthyan bycatch species taken in the Southern and Eastern Scalefish and Shark Fishery. Final report to Fisheries Research and Development Coporation Project No. 2002/033. 354 p.

Wigham, B., Hudson, I., Billett, D., \& Wolff, G. (2003). Is long-term change in the abyssal Northeast Atlantic driven by qualitative changes in export flux? Evidence from selective feeding in deep-sea holothurians. Progress in oceanography, 59, 409-441.

Williams, A., Schlacher, T.A., Rowden, A.A., Althaus, F., Clark, M. R., Bowden, D.A., Stewart, R., Bax, N.J., Consalvey, M. \& Kloser, R.J. (2010). Seamount megabenthic assemblages fail to recover from trawling impacts. Marine Ecology, 31, 183-199.

Yates, F. (1934). Contingency table involving small numbers and the $\chi^{2}$ test. Supplement to the Journal of the Royal Statistical Society, 1, 217-235. 